\title{
Quality of Processing Tomato Fruits in Competition with Solanum americanum ${ }^{1}$
}

\author{
Qualidade de Frutos de Tomate para Indústria em Competição com Solanum americanum
}

\author{
PORTUGAL, J. ${ }^{2}$, REGO, F.C. ${ }^{3}$, MOREIRA, I. ${ }^{4}$, and VIDAL, R.A. ${ }^{5}$
}

\begin{abstract}
Five experiments were conducted to evaluate the hypothesis that Solanum americanum density and time of coexistence affect the quality of processing tomato fruit. The tomato crop was established using either the direct drilling or the transplanting technique. The factors evaluated consisted of weed density (from 0 up to 6 plants $\mathrm{m}^{-2}$ ) and time of weed interference (early bloom stage, full flowering stage, fruit filling, and harvest time). The effects of competition on tomato fruit quality were analysed using a multiple model. Tomato variables evaluated included industrial fruit types (which depended on ripeness and disease infection) and soluble solids level ( ${ }^{\circ}$ brix). Tomato fruit quality is dependent on the factors tested. Under low densities $\left(<6\right.$ plants $\left.\mathrm{m}^{-2}\right)$ of $S$. americanum there was a small impact on the quality of the tomato fruits. The percentage of grade A (mature fruit with red color and without pathogen infection) tomato fruits is the variable most affect by the independent variables. The impact of these independent variables on the percentage of grade $\mathrm{C}$ (green and/or with more than $15 \%$ disease infection) tomato yield was of smaller magnitude and in an inverse trend as the observed for grade A. The level of soluble solids was influenced by the weed interference on only two experiments, but the impact was of small magnitude. The impact of the results on current and future crop management practices is discussed.
\end{abstract}

Keywords: weed competition, critical period, density-dependent processes, threshold.

RESUMO - Cinco experimentos foram conduzidos para avaliar a hipótese de que a densidade de Solanum americanum e tempo de convivência podem alterar a qualidade dos frutos do tomate para a indústria. O tomate foi cultivado usando-se o plantio direto ou a técnica de transplante. Os fatores avaliados consistiram da densidade de plantas daninhas (de 0 até 6 plantas $\mathrm{m}^{-2}$ ) e do tempo de interferência delas (fases de pré-florada, pleno florescimento, enchimento de frutos e colheita). Os efeitos da interferência sobre a qualidade dos frutos do tomateiro foram analisados utilizando um modelo múltiplo. As variáveis de tomate avaliadas foram tipos de fruta para indústria (em função da maturação e infecção da doença) e teor de sólidos solúveis ( ${ }^{\circ}$ brix). A qualidade dos frutos de tomate é dependente dos fatores testados. Sob baixa densidade ( $<6$ plantas $\left.m^{-2}\right)$ de $\mathbf{S}$. americanum, houve reduzido impacto sobre a qualidade dos frutos do tomateiro. A porcentagem de frutos tipo $A$ (fruta madura, com cor vermelha e sem infecção por patógeno) é a variável mais afetada pela interferência das plantas daninhas. O impacto das variáveis independentes sobre a porcentagem de frutos tipo C (verde e/ ou com mais de 15\% de infecção da doença) foi de baixa magnitude e com tendência inversa ao observado para a classe A. O nível de sólidos solúveis foi influenciado pela interferência das plantas daninhas em apenas dois experimentos, mas o impacto foi de pequena magnitude. Discute-se neste estudo o impacto dos resultados sobre as práticas de manejo de culturas atuais e futuras.

Palavras-chave: interferência, período crítico, processos dependentes da densidade, nível de dano econômico.

Recebido para publicação em 9.6.2015 e aprovado em 11.8.2015.

2 Instituto Politécnico de Beja (IPBeja), Beja, Portugal; ${ }^{3}$ Universidade de Lisboa (UL), Lisboa, Portugal; ${ }^{4}$ Instituto Superior de Agronomia, Tapada da Ajuda, Lisboa, Portugal (in memorian); ${ }^{5}$ Universidade Federal do Rio Grande do Sul (UFRGS), Porto Alegre-RS, Brasil. 


\section{INTRODUCTION}

The world production of tomato in 2012 reached 159 million $\mathrm{t}$ of fruit yield and with an average productivity of $33 \mathrm{t} \mathrm{ha}^{-1}$ (FAO, 2013). The impact of weeds on the tomato yield is dependent both on the weed density and on the period of the weed interference on the crop (Portugal \& Moreira, 2009, 2011; Portugal \& Vidal, 2009), among other factors. When analyzed under very low weed density, the tomato yield loss is positive and linearly related to infestation (Portugal \& Moreira, 2009). However, when studied through a wide range of weed densities, the crop yield loss follows a rectangular hyperbole model (Cousens, 1985; Portugal \& Vidal, 2009). When weed density and time of interference are analyzed together, it is possible to establish tolerance levels for the weed infestation before any economic impact on the crop yield and quality can be detected (Portugal \& Vidal, 2009; Portugal \& Moreira, 2011).

The tomato fruit quality is determined by at least two variables: fruit type and total solid soluble (Beckles et al., 2012). The fruit type is classified according to the color and sanity of tomato fruits. Mature fruits with red color and without pathogen infections are classified as grade A tomato; partially green or yellow with less than $15 \%$ disease infection are qualified as grade $\mathrm{B}$; and grade $\mathrm{C}$ is attributed to fruits over matured or with more than $15 \%$ disease infection (Sutton et al., 2006; Beckles et al., 2012). The total of soluble solids ( ${ }^{\circ} \mathrm{brix}$ ) is determined using a refractometric index that indicates the percentage of soluble in a solution. The solutes consist of a mixture of several chemicals in which predominate sugars $(65 \%)$, acids $(13 \%)$ and other compounds (mainly amino acids, ascorbate, minerals, pectins, and phenols) (Beckles, 2012; Iglesias et al., 2015).

The hypothesis that weed interference decreases the quality of the crop products is supported in several crops. For instance, there is evidence that weeds reduce the acidity and the amount of vitamin $\mathrm{C}$ of mandarin (Citrus reticulata) fruits (Abouziena et al., 2008); decrease the sucrose content of suggarbeets (Beta vulgaris subsp. vulgaris) (Paolini et al., 1999); reduce cotton (Gossypium hirsutum) fiber properties like micronaire and strength (Wood et al., 1999); and diminish the size of several crop products such as onion (Allium cepa) bulbs (Williams et al., 2004); cranberry (Vaccinium oxycoccos) fruits (Patten \& Wang, 1994) and sweet potatoes (Ipomoea batatas) roots (Meyers et al., 2010). However, of the few reports on the weed impact on the quality of the tomato crop fruits (Friesen, 1979; Caussanel et al., 1990; McGiffen et al., 1994; Buckelew \& Monks, 2006; Sutton et al., 2006) there is no clear evidence of this hypothesis. For example, whereas there is an inverse relationship between Solanum ptycanthum density and large tomato fruits (Mcgiffen et al., 1994; Buckelew $\&$ Monks, 2006), there is no impact of the weed on the number of small fruits (Buckelew \& Monks, 2006). Likewise, there is no evidence of the impact of weeds on the brix values of the tomato fruits (Sutton et al., 2006).

Solanum americanum Mill. (black nightshade) is a weed species from the Solanaceae family that reduces tomato crop yield. The objective of the present report is to evaluate whether $S$. americanum plant density and period of weed-crop coexistence affect the quality of processing tomato fruits.

\section{MATERIAL AND METHODS}

Five field experiments were conducted between 1991 and 2001 on the tomato growing region in Southern Portugal. A factorial arrangement of the treatments was designed and the independent variables included weed density (factor A) and time of weed interference (factor B) as shown in Table 1. Each treatment was repeated at least four times on each experiment. Cropping systems investigated ranged from direct drilling to transplanted (Table 1). Other characteristics of the experiments such as year, location, clay soil content are summarized on Table 1 and were already reported (Portugal \& Moreira, 2009). The fertilization was made according to the soil analysis and to attend the crop requirements to optimize the crop yield. Irrigation was provided as needed.

After crop harvest, tomato fruits were separated into three categories described above (Sutton et al., 2006; Beckles et al., 2012), hereon called as red (A grade), green (B grade) 
Table 1 - Year, location, soil clay content, cropping system, and experimental characteristics of the five trials conducted to evaluate impact of the time of interference and density of Solanum americanum on Solanum lycopersicum fruit quality

\begin{tabular}{|c|c|c|c|c|c|}
\hline & Trial 1 & Trial 2 & Trial 3 & Trial 4 & Trial 5 \\
\hline Year & 1991 & 1994 & 1998 & 1999 & 2001 \\
\hline Location in Portugal & Ferreira do Alentejo & Beringel & Beja & Beja & Beja \\
\hline Soil clay content (\%) & 19.9 & 17.5 & 38.0 & 30.6 & 33.6 \\
\hline Cropping systems & Direct sowing & Transplant & Transplant & Direct sowing & Direct sowing \\
\hline Plot size $\left(\mathrm{m}^{2}\right)$ & 2 & 3 & 2 & 2 & 2 \\
\hline $\begin{array}{l}\text { Time of weed interference } \\
\text { (from crop emergence up to) }\end{array}$ & $\begin{array}{l}\text { a- first flowers } \\
\text { b- full bloom } \\
\text { c- first fruits } \\
\text { d- harvest }\end{array}$ & $\begin{array}{l}\text { a- first flowers } \\
\text { b- full bloom } \\
\text { c- first red fruits } \\
\text { d- fruit maturity } \\
\text { e- harvest }\end{array}$ & $\begin{array}{c}\text { a- first flowers } \\
\text { b- full bloom } \\
\text { c- harvest }\end{array}$ & $\begin{array}{l}\text { a- first flowers } \\
\text { b- full bloom } \\
\text { c- first red fruits } \\
\text { d- harvest }\end{array}$ & $\begin{array}{l}\text { a- first flowers } \\
\text { b- full bloom } \\
\text { c- first red fruits } \\
\text { d- harvest }\end{array}$ \\
\hline Weed density (plants $\mathrm{m}^{-2}$ ) & $0 ; 1 ; 3 ; 6$ & $0 ; 1 ; 3 ; 6$ & $0 ; 1 ; 2 ; 3$ & $0 ; 0.5 ; 1 ; 1.5$ & $0 ; 0.5 ; 1 ; 1.5$ \\
\hline
\end{tabular}

and rot ( $\mathrm{C}$ grade). On each category, the fruit mass was determined and the proportion of each class in relation to the total fruit mass was calculated. A sample of red fruits was selected to brix determination. The fruits were cut in quarters and blended using an industrial food processor. Afterwards, the total soluble solids was evaluated with a refractometer (Atago PR101), with the precision of \pm 0.1 obrix.

The data was adjusted to a multiple model described by Portugal \& Moreira (2011) and summarized as:

$$
\begin{aligned}
\mathrm{Y} & =\text { const }+b \text { dens }+c \text { dens }^{2}+d \text { tds } \\
& +e \operatorname{tds}^{2}+f \text { dens } \times \text { tds }
\end{aligned}
$$

where the dependent variable (Y) is the proportion (percentage) of certain tomato fruit type or the brix value; whereas the independent variables are: weed density (dens), square of dens (dens ${ }^{2}$ ), number of days for weed interference (tds), the square of tds $\left(t d s^{2}\right)$, and the association of both dens and tds (dens $x$ tds). The coefficients const (constant), $b, c, d, e$, and $f$ represents the equation parameters. Hereafter this model will be referred to as non linear multiple model (Portugal \& Moreira, 2011). Because a preliminary analysis of variance indicated an effect of the year, a non linear multiple model was adjusted to each experiment. The equations were obtained using the treatment average to reduce data variability of the treatment repetitions. The residual sum of squares and the adjusted coefficient of determinations $\left(\mathrm{R}^{2}\right)$ were used to indicate the fitness of the models. The statistical program
SPSS (Statistical Package for Social Sciences, version 11.0, IBM) was used to evaluate the significance of each equation parameter with the Student $t$ test, whereas the significance of the whole equation was evaluated with the F test.

\section{RESULTS AND DISCUSSION}

Total tomato fruit yield in weed-free conditions ranged from 110 to $157 \mathrm{t} \mathrm{ha}^{-1}$ among all the years. When competing with the crop during the whole season, S. americanum at a density of 1 plant $\mathrm{m}^{-2}$ decreases tomato productivity by $4 \%$ up to $23 \%$, in the transplanted and direct drilling planting system, respectively (Figure 1).

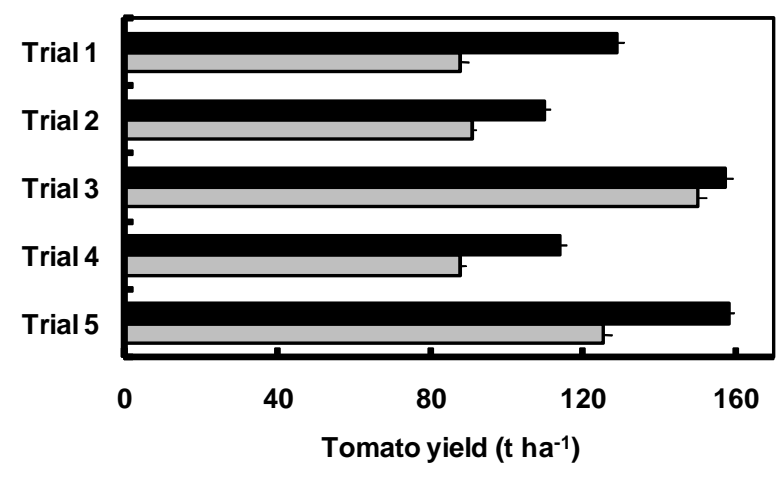

Figure 1 - Tomato yield (t ha-1) in weed-free (black bars) treatments and in coexistence during the whole season with Solanum americanum (grey bars) at the density of 1 plant $\mathrm{m}^{-2}$. Black lines indicate the standard error of the estimative of the mean. Each bar is the average of at least four repetitions. 
The results of the $\mathrm{F}$ test yielded significant $(\mathrm{P}<0.05)$ equations for red fruits on trials 1 and 2. Significant $(\mathrm{P}<0.05)$ equations were identified for rot tomatoes for trials $1,2,3$, and 5. Likewise, significant equations $(\mathrm{P}<0.05)$ were detected for the variable total solid soluble on trials 1 and 5 . Finally, on trial 4 there were no significant $(\mathrm{P}>0.05)$ equations for any of the tomato quality variables assessed (Table 2).

\section{Tomato from red category (A grade)}

In trials with weed density of 0 to 6 plants $\mathrm{m}^{-2}$ (trials 1 and 2), the combined effect of the weed density and the time of competition influenced the variation of the tomato grade A production (Table 2 and Figure 2). On trials 1 and 2, respectively, the non linear multiple models can explain $61 \%$ and $48 \%$ of the impact of the independent variables on the A grade tomato production.

Obtained data indicates that the increase of the competition period and plant density affected the percentage of grade A tomato fruits. On trial 1 , the effect of weed density on grade A tomato production was limited at low $S$. americanum densities $\left(<3\right.$ plants $\left.\mathrm{m}^{-2}\right)$. At these weed densities, when the weed interacted with the crop up to 45 days after emergence (DAE) the A grade tomato yielded approximately $70 \%$ of the total of fruits produced. However, crop interaction with low weed densities $\left(<2\right.$ plants $\left.\mathrm{m}^{-2}\right)$ up to $105 \mathrm{DAE}$ produced about $60 \%$ of A grade tomato. As the weed densities increased to 6 plants $\mathrm{m}^{-2}$, the A grade tomato production reached up to $80 \%$, independent on the period of weed-crop interaction (Figure 2).

Table 2 - Parameters of the non linear multiple model ${ }^{1 /}$ to quality variables (QVar) of tomato fruits as affected by Solanum americanum density and time of weed-crop coexistence, evaluated on five field experiments

\begin{tabular}{|c|c|c|c|c|c|c|c|c|c|}
\hline Trial & $\mathrm{QVar}^{2 /}$ & const & $\mathrm{b}$ & C & d & e & $\mathrm{f}$ & $\mathrm{R}^{2} \mathrm{adj}^{\underline{3} /}$ & $\mathrm{F}$ \\
\hline \multirow{4}{*}{ 苞 } & A & $113.201^{* * *}$ & -2.469 & -0.095 & $-1.152 *$ & $0.008 *$ & 0.030 & 0.608 & $5.645 * \underline{4}$ \\
\hline & B & -9.983 & -0.438 & 0.098 & 0.701 & $-0.005^{*}$ & -0.002 & 0.267 & 2.091 \\
\hline & $\mathrm{C}$ & -3.219 & 2.906* & -0.003 & $0.451 *$ & $-0.003 *$ & $-0.028 *$ & 0.769 & $10.989 * *$ \\
\hline & SSol & $3.264^{* *}$ & 0.013 & -0.035 & $0.054 *$ & $-0.0004^{*}$ & $0.003 *$ & 0.624 & $5.970 * *$ \\
\hline \multirow{4}{*}{$\begin{array}{l}\frac{N}{\widetilde{Z}} \\
\vec{E}\end{array}$} & $\mathrm{~A}$ & 72.073* & -3.126 & 0.107 & 0.026 & -0.00008 & $0.041 *$ & 0.481 & $4.517^{*}$ \\
\hline & $\mathrm{B}$ & 16.280 & 1.949 & -0.028 & -0.082 & 0.0007 & -0.025 & 0.183 & 1.850 \\
\hline & C & 8.319 & 1.291 & -0.069 & 0.132 & -0.001 & $-0.017 *$ & 0.408 & $3.623 *$ \\
\hline & SSol & $3.985^{*}$ & 0.318 & -0.031 & 0.014 & -0.0001 & -0.0007 & 0.311 & 2.717 \\
\hline \multirow{4}{*}{$\begin{array}{l}m \\
\stackrel{n}{\Xi} \\
E\end{array}$} & A & $69.502 * *$ & -3.138 & 0.525 & 0.185 & -0.001 & 0.024 & 0.015 & 1.035 \\
\hline & $\mathrm{B}$ & 12.871 & 1.723 & -0.267 & 0.162 & -0.001 & -0.014 & -0.377 & 0.397 \\
\hline & C & $17.627^{* *}$ & 1.415 & -0.258 & $-0.347^{*}$ & $0.003^{*}$ & -0.009 & 0.674 & 5.553* \\
\hline & SSol & $5.539 * *$ & -0.236 & 0.056 & -0.043 & 0.000 & 0.002 & 0.338 & 2.125 \\
\hline \multirow{4}{*}{$\stackrel{\nabla}{\stackrel{\Xi}{\Xi}}$} & A & $63.494 * * *$ & -4.331 & -1.410 & 0.205 & -0.002 & 0.103 & 0.006 & 1.018 \\
\hline & B & 16.125 & -0.952 & 5.159 & 0.128 & 0.000 & -0.125 & 0.304 & 2.311 \\
\hline & $\mathrm{C}$ & 20.411 & 5.288 & -3.747 & -0.334 & 0.002 & 0.022 & 0.021 & 1.065 \\
\hline & SSol & $5.495 * * *$ & 0.118 & -0.118 & 0.004 & -0.00007 & 0.002 & -0.029 & 0.914 \\
\hline \multirow{4}{*}{$\frac{10}{.]}$} & A & $61.329 * *$ & 5.018 & -1.763 & 0.304 & -0.002 & 0.0001 & 0.006 & 1.020 \\
\hline & B & 8.858 & 2.293 & -1.092 & 0.059 & -0.0004 & -0.00007 & -0.390 & 0.159 \\
\hline & $\mathrm{C}$ & $29.814^{* *}$ & -7.307 & 2.852 & -0.364 & 0.002 & -0.0005 & 0.519 & 4.238* \\
\hline & SSol & $7.315^{* * *}$ & $-1.211^{* *}$ & $0.670^{* *}$ & -0.040 & 0.0003 & 0.00001 & 0.547 & $4.623 *$ \\
\hline
\end{tabular}

$\underline{1}^{\prime} \mathrm{Y}=\mathbf{c o n s t}+\mathbf{b}$ dens $+\mathbf{c}$ dens ${ }^{2}+\mathbf{d}$ tds $+\mathbf{e}$ tds ${ }^{2}+\mathbf{f}$ dens $\mathrm{x}$ tds; where const $=$ equation constant, $\mathrm{b}, \mathrm{c}, \mathrm{d}, \mathrm{e}$, and $\mathrm{f}=$ equation coefficients, dens= density, and tds= time of weed interference. ${ }^{2 /}$ The quality of the tomatoes were measured by fruit types (grade $\mathrm{A}=$ mature fruit with red color and without pathogen infections; grade $\mathrm{B}=$ partially green or yellow and/or with less than $15 \%$ infection; grade $\mathrm{C}=$ over matured and/ or with more than $15 \%$ disease infection and content of soluble solids. $\stackrel{3}{3}$ Coefficient of determination of nonlinear model with a defined intercept and calculated as $\mathrm{r}^{2}$ adj $=1$ - (sums of squares of the regression/corrected total sums of squares). ${ }^{4 /}$ Statistical significance is indicated by the astheristics as follows: ${ }^{*} \mathrm{P}<0.05 ;{ }^{*} \mathrm{P}<0.01 ;{ }^{* * *} \mathrm{P}<0.001$. Student $\mathrm{t}$ test was used to evaluate significance of equation parameters and $\mathrm{F}$ test was used to evaluate the whole model. No astheristic indicates no significance $(\mathrm{P}>0.95)$. 
Trial 1

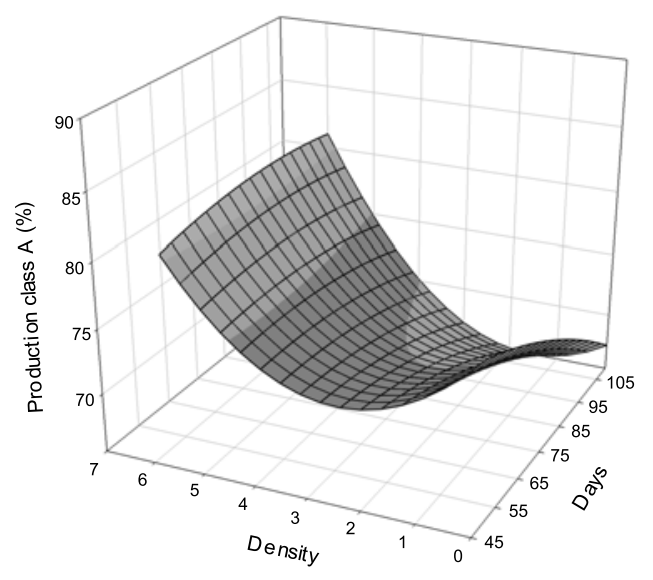

Trial 2

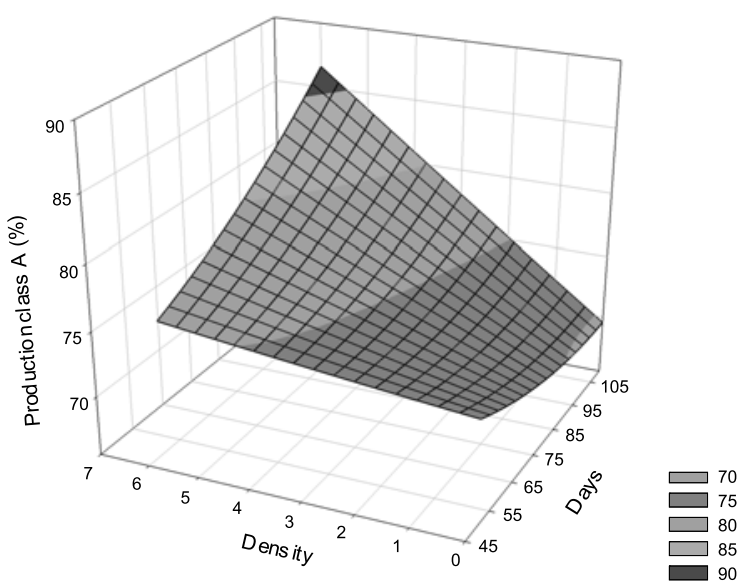

Figure 2 - Tomato fruit class A grade as affected by density and time of interference of Solanum americanum on two experiments. Shown here only the graphical representation of significant equations (see Table 2).

On trial 2, the A grade tomato yielded $70 \%$ of the total of fruits produced at low $S$. americanum densities $\left(<1\right.$ plant $\left.\mathrm{m}^{-2}\right)$, independent on the periods tested for weedcrop coexistence. At weed-crop coexistence of 0 to 45 DAE and weed density of 6 plants $\mathrm{m}^{-2}$, the A grade tomato yielded $75 \%$ of the total of tomato fruits produced. With season long weed-crop coexistence, high $S$. americanum density ( 6 plants $\mathrm{m}^{-2}$ ) increased the tomato grade A up to $85 \%$ of the total of fruits produced (Figure 2).

\section{Tomato from rot category (C grade)}

The non linear multiple models can explain $77 \%, 41 \%, 67 \%$ and $52 \%$ of the impact of the independent variables on the $\mathrm{C}$ grade tomato production on trials $1,2,3$ and 5 , respectively. The impact of the treatments on the percentage of the $\mathrm{C}$ grade tomato production was very limited and ranged from 10 and $22 \%$ on trial 1 , and between 10 and $14 \%$ on trials 2,3 , and 5 (Figure 3 ). These results occurred despite the differences in experimental settings described on Table 1.

On trial 1, when $S$. americanum coexisted with the tomato plants up to $45 \mathrm{DAE}$, the $\mathrm{C}$ grade tomato production ranged from 10 to $14 \%$, independent on the weed density. However, for season long weed-crop coexistence, the increase of $S$. americanum density from 0 to 6 plants $\mathrm{m}^{-2}$ reduced the C grade tomato from $22 \%$ to $10 \%$ of the total of fruits produced, respectively.

On trial 2, the percentage of $\mathrm{C}$ grade tomato production was situated between 10 and $12 \%$, when the weed-crop coexisted up to 45 or up to $105 \mathrm{DAE}$, respectively. With the increment of the $S$. americanum density from 0 to 7 plants $\mathrm{m}^{-2}$, the percentage of $\mathrm{C}$ grade tomato production decreased to 10\% (Figure 3).

Overall, on trial 3 , regardless the S. americanum density, the number of days of weed-crop coexistence had a quadratic effect on the $\mathrm{C}$ grade tomato production. In fact, when the weed-crop coexisted for 60 days after transplant, the $\mathrm{C}$ grade tomato percentage reached the minimum value $(8 \%)$. However, the $\mathrm{C}$ grade tomato percentage reached value up to $12 \%$ for limited or longer periods of weed interference (Figure 3).

On trial 5, both the period of weed-crop coexistence and the $S$. americanum density had a quadratic effect, but of limited magnitude (from 10 to $14 \%$ ), on the $\mathrm{C}$ grade tomato production (Figure 3 ). The highest percentage of $\mathrm{C}$ grade tomato production was approximately $14 \%$ and was obtained in the absence of weed interference. For S. americanum density up to 1.5 plants $\mathrm{m}^{-2}$ and when the weed-crop coexisted up to 45 days after the transplant, the $\mathrm{C}$ grade tomato 
Trial 1

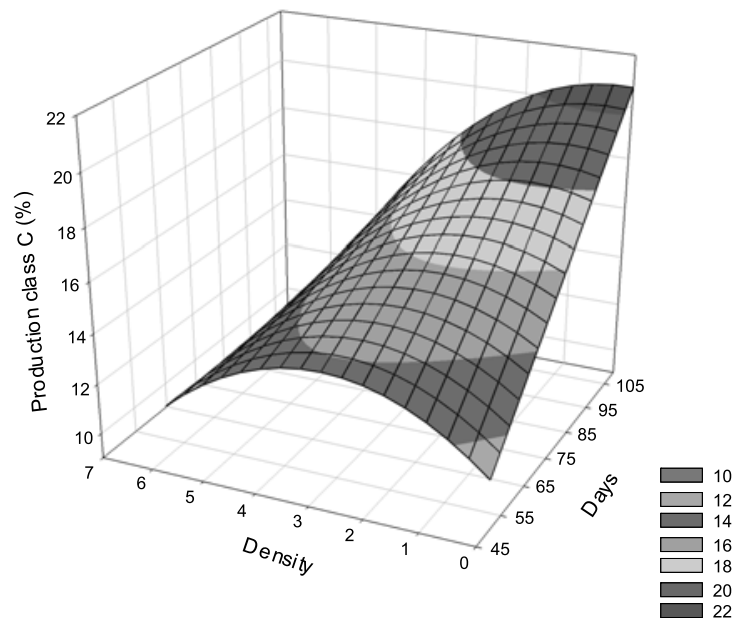

Trial 3

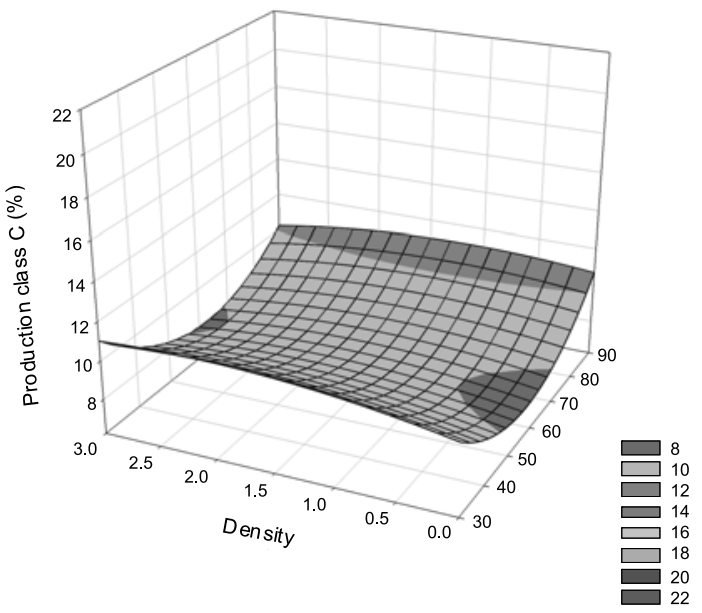

Trial 2

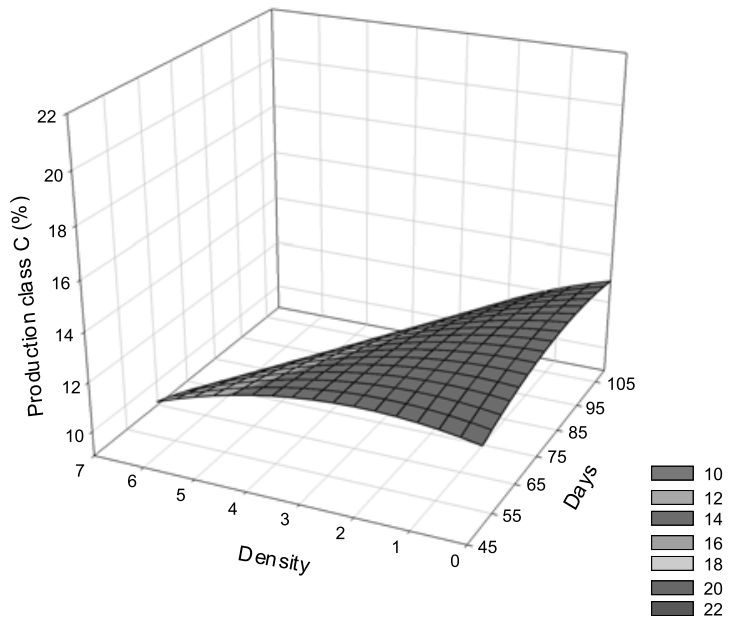

Trial 5

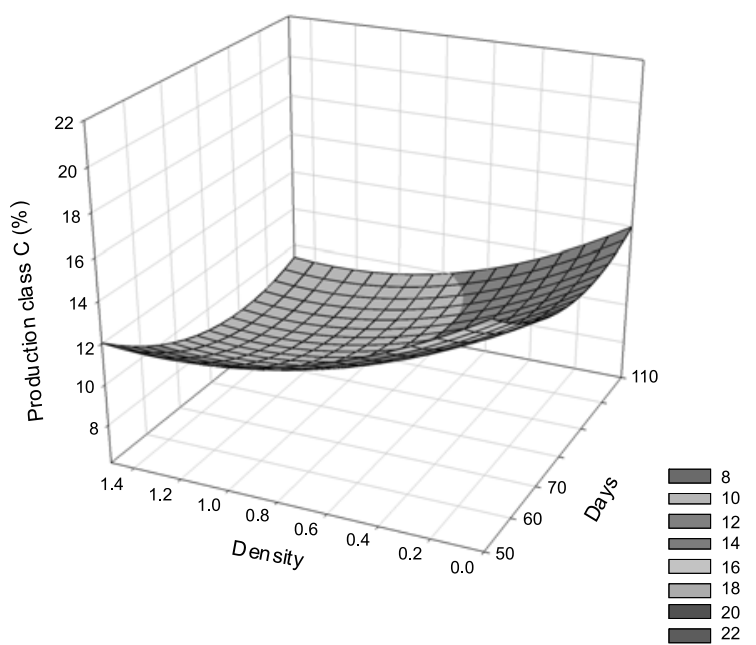

Figure 3 - Tomato fruit class C grade as affected by density and time of interference of Solanum americanum on four experiments. Shown here only the graphical representation of significant equations (see Table 2).

production decreased to $12 \%$. However, when the weed density increased at the same magnitude but the weed-crop coexisted during the whole season, the $\mathrm{C}$ grade tomato production decreased to $10 \%$ (Figure 3 ).

\section{Total soluble solids ( $\left.{ }^{\circ} \mathrm{brix}\right)$}

The non linear multiple models can explain $62 \%$ and $55 \%$ of the impact of the independent variables on the soluble solids of the tomato fruits on the trials 1 and 5, respectively (Table 2). On both experiments, the magnitude of the variation of the soluble solids was very limited, ranging from 4.5 and $5.5^{\circ}$ brix on trial 1 , and from 5.5 to $6.5^{\circ}$ on trial 5. Also, on both trials, the independent variables had a quadratic impact on the dependent variable. However, the overall trend of the effect of the variables were opposite on both trials (Figure 4). On trial 1, the maximum value of the solid soluble was 
approximately $5.5^{\circ}$, which was observed when the $S$. americanum density corresponded to 3 plants $\mathrm{m}^{-2}$ in coexistence with the crop up to $85 \mathrm{DAE}$. On trial 5 , the minimum value of the solid soluble was approximately $5.5^{\circ}$ brix, which was achieved at $S$. americanum density of 1 plants $\mathrm{m}^{-2}$ in coexistence with the crop up to 70 DAE (Figure 4).

The experiments in this research were designed to evaluate the impact of very low weed densities and different periods of weedcrop coexistence on tomato fruit quality. The crop on the first trial was established in a direct sowing system, thus the weed and crop plants would have similar start establishment. Since the competition of the $S$. americanum plants was intense (Figure 1), the crop plants on the second experiment were transplanted in order to provide them a competitive advantage in relation to the weeds. On the third experiment, the crop plants were also transplanted, but the maximum weed density was reduced to $50 \%$ ( 3 plants $\mathrm{m}^{-2}$ ) from the previous experiment. For the following two experiments, the cropping system was direct sowing and the maximum weed density was reduced to 1.5 plants $\mathrm{m}^{-2}$ (Table 1$)$. The results demonstrate that $S$. americanum is a very competitive weed species which affects the quality of tomato fruits, even under very limited weed densities or during reduced weed-crop coexistence periods (Figures 2, 3, 4 and Table 2).

All results on tomato fruit quality presented here are likely to be a consequence of the environmental limitations imposed by the weeds. Thus the fact that increased weed-crop coexistence (either through density or time) augmented the production of red tomatoes (Trials 1, 2; Figure 2, Table 2) offsets, in our interpretation, the decrease in the percentage of rot tomatoes (trials 1, 2, 3, 4; Figure 3; Table 2). These results are not surprising and may be explained by at least three causes. First, resource competition is likely to have restricted water availability with subsequent reduction of cell enlargement during the crucial periods of tomato fruit formation (Beckles et al., 2012) and delaying its maturity. Considering that anthropogenic climate change may increase the drought occurrences in the Mediterranean region (Jacobeit et al., 2014), the results of this research suggest that the tolerance level of $S$. americanum in tomato crop may decrease in the future or that the crop would require increased irrigation to offset the impact of the weeds on the tomato quality. From this reasoning it is possible to speculate that weed management practices will have to be
Trial 1

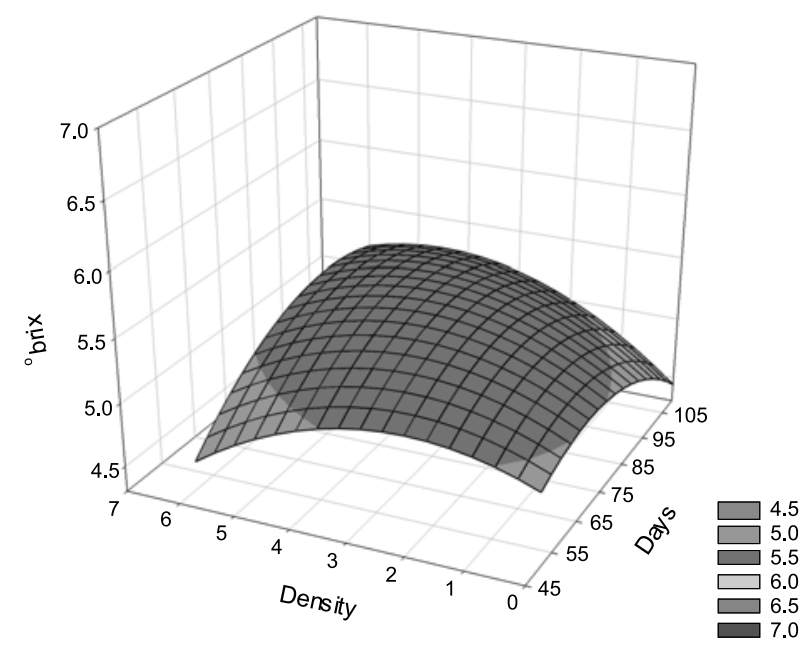

Trial 5

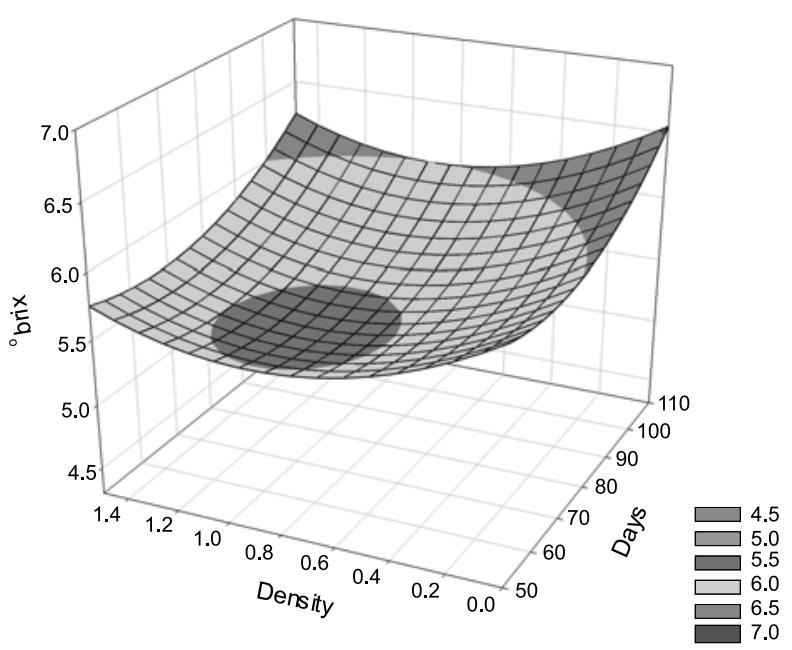

Figure 4 - Content of soluble solids ( ${ }^{\circ}$ brix) of tomato fruits as affected by density and time of interference of Solanum americanum on two experiments. Shown here only the graphical representation of significant equations (see Table 2). 
intensified to minimize losses on tomato crop yield and quality.

Second, reduced water availability may have restricted nutrient (mainly $\mathrm{N}$ and K) uptake by the tomato plants, hence accumulating starch on the fruits and consequently affecting the brix values on the tomato fruits (Cuartero \& Fernandez-Munoz, 1999; Saito et al., 2006).

Third, the presence of the weeds may have altered the light quality and availability to the crop, which would further impact the fruit quality (Gautier et al., 2008). Indeed, the weed present during the early stages of the crop development may have altered light quality, thus affecting the crop root morphology, as described on the initialism mechanism of weed-crop interaction (Vidal et al., 2012). When the weeds were removed latter in the growing season, the crop roots could not recover their original morphology, and during the time of weed-crop coexistence the sunlight damage to fruits would be restricted. However, if the weeds were allowed in the crop until the harvest, the microenvironment might become favorable for fruit rotting.

The results presented here also support the concept that botanical similarity between weed and crop species would engender strong weed-crop interference. Indeed, we have taken all the procedures to test weed densities at their minimum to achieve the tolerance level (Portugal \& Vidal, 2009). But even in these conditions, some of the tomato quality variables were affected. We interpreted the fact that not all experiments have evidenced the impact of $S$. americanum interference on the tomato quality variables measured as an indicator that the tolerance level was reached. The results presented here indicate that $S$. americanum at very low densities and at limited time of interference may have a positive impact on the quality of the tomato fruits, namely the production of grade $\mathrm{A}$ and total solid soluble. However, it is worth mentioning that from five experiments, in only two experiments there was an increased on percentage of grade A tomatoes (Figure 2) and on the amount of total solid soluble (Figure 4). Also, these effects are not always consistent during all years (Caussanel, 1990). Yet, it is important to mention that these small benefits would not offset the yield loss caused by $S$. americanum, even at very low weed density, on the tomato productivity (Figure 1).

The non linear multiple model presented here has the benefit to demonstrate that the weed density and the period the weed-crop coexistence are mutually dependent. In other words, this model allows understanding during how long a certain weed density can be tolerated by the crop. The information provided is much superior to either factor analyzed isolated. In practical terms, the results presented here highlight the importance of proper weed management prior the crop establishment (either through cultural, chemical, mechanical or a combination of methods) to reduce their density to a minimum and, also, the need of their removal during the crop development, even at very low weed densities.

Tomato fruit quality is dependent on Solanum americanum density and period of coexistence with the crop. Low densities $\left(<6\right.$ plants $\left.\mathrm{m}^{-2}\right)$ of $S$. americanum had a small impact on the quality of the tomato fruits. The percentage of grade A tomato fruits is the variable most affect by the weed interference and it is increased with the increment weed-crop coexistence period and with the $S$. americanum density. The impact of these independent variables on the percentage of grade $\mathrm{C}$ tomato yield was of smaller magnitude and in an inverse trend as the observed for grade A. The level of soluble solids was influenced by the weed interference but the impact was of small magnitude.

\section{ACKNOWLEDGEMENTS}

The authors are indebted to Dr. Neumarcio Costa for his help in figures preparation.

\section{LITERATURE CITED}

ABOUZIENA, H. F. et al. Comparison of weed suppression and mandarin fruit yield and quality obtained with organic mulches, synthetic mulches, cultivation, and glyphosate.

Hortscience, v. 43, n. 3, p. 795-799, 2008.

BECKLES, D. M. et al. Biochemical factors contributing to tomato fruit sugar content: a review. Fruits, v. 67, n. 1, p. 49-64, 2012. 
BECKLES, D. M. Factors affecting the postharvest sugars and total soluble solids in tomato (Solanum lycopersicum L.) fruits. Posth. Biol. Technol., v. 63, n. 1, p. 129-140, 2012.

BUCKELEW, J. K.; MONKS, D. W. Effect of eastern black nightshade (Solanum ptycanthum) on transplanted plasticulture tomato grade and yield. Weed Sci., v. 54, n. 3, p. 504-508, 2006.

CAUSSANEL, J. P. et al. Influence de la densité et de la période de concurrence de Solanum nigrum L. sur la tomate de semis direct, en relation avec le désherbage. Weed Res., v. 30, n. 5, p. 341-354, 1990.

COUSENS, R. A simple model relating yield loss to weed density. Ann. Appl. Biol., v. 107, n. 2, p. 239-252, 1985.

CUARTERO, J.; FERNANDEZ-MUNOZ, R. Tomato and salinity. Sci. Hortic., v. 78, n. 1, p. 83-125, 1999.

FAO. FAO statistical yearbook 2013. Rome: FAO, 2013. Available at: <http://www.fao.org/docrep/018/i3107e/ i3107e00.htm>. Last accessed: 12 Jan. 2015.

FRIENSEN, G. H. Weed interference in transplanted tomatoes. Weed Sci., v. 27, n. 1, p. 11-13, 1979.

GAUTIER, H. et al. How does tomato quality (sugar, acid, and nutritional quality) vary with ripening stage, temperature, and irradiance? J. Agric. Food Chem., v. 56, n. 4, p. 1241-1250, 2008.

IGLESIAS, M. J. et al. Differential response to environmental and nutritional factors of high-quality tomato varieties. Food Chem., v. 176, p. 278-287, 2015.

JACOBEIT, J. et al. Statistical downscaling for climate change projections in the Mediterranean region: methods and results. Reg. Environ. Change, v. 14, n. 5, p. 1891-1906, 2014.

MCGIFFEN, M. E.; PANTONE, D. J.; MASIUNAS, J. B. Path-analysis of tomato yield components in relation to competition with black and eastern black nightshade. J. Am. Soc. Hortic. Sci., v. 119, n. 1, p. 6-11, 1994.

MEYERS, S. L. et al. Interference of Palmer Amaranth (Amaranthus palmeri) in sweet potato. Weed Sci., v. 58, n. 3, p. 199-203, 2010.
PAOLINI, R. et al. Competition between sugarbeet and Sinapis arvensis and Chenopodium album, as affected by timing of nitrogen fertilization. Weed Res., v. 39, n. 6, p. 425-440, 1999.

PATTEN, K. D.; WANG, J. Cranberry yield and fruit quality reduction caused by weed competition. Hortscience, v. 29, n. 10, p. 1127-1130, 1994.

PORTUGAL, J. M.; MOREIRA, I. Impacto da erva-moira na produção do tomateiro e ajuste de modelos matemáticos. Planta Daninha, v. 27, p. 901-911, 2009. (Número especial)

PORTUGAL, J. M.; MOREIRA, I. Aplicação de modelos múltiplos na determinação de níveis de prejuízo para a interacção Solanum americanum e tomate de indústria. Planta Daninha, v. 29, n. 4, p. 751-760, 2011.

PORTUGAL, J. M.; VIDAL, R. A. Níveis econômicos de prejuízos de plantas infestantes nas culturas agrícolas: conceitos, definições e formas de cálculo. Planta Daninha, v. 27, n. 4, p. 869-877, 2009.

SAITO, T.; FUKUDA, N.; NISHIMURA, S. Effects of salinity treatment duration and planting density on size and sugar content of hydroponically grown tomato fruits. J. Japanese Soc. Hortic. Sci., v. 75, n. 5, p. 392-398, 2006.

SUTTON, K. F. et al. Weed control, yield, and quality of processing tomato production under different irrigation, tillage, and herbicide systems. Weed Technol., v. 20, n. 4, p. 831-838, 2006.

VIDAL, R. A. et al. Initialism as a mechanism of weed interference: can a crop plant be blinded? Planta Daninha, v. 30, n. 3, p. 469-475, 2012.

WILLIAMS, M. M.; RANSOM, C. V.; THOMPSON, W. M. Effect of volunteer potato density on bulb onion yield and quality. Weed Sci., v. 52, n. 5, p. 754-758, 2004.

WOOD, M. L. et al. Full-season interference of Ipomoea hederacea with Gossypium hirsutum. Weed Sci., v. 47, n. 6, p. 693-696, 1999. 